\title{
Pengaruh Model Pembelajaran Generatif Terhadap Kemampuan Pemahaman Konsep Matematis Siswa Kelas VIII SMP Negeri 12 Kendari
}

\author{
(The Influence Of Generative Learning Models On The Ability Of Understanding The \\ Mathematical Concept Of Class VIII Students Of SMP Negeri 12 Kendari)
}

\author{
Zuari Anzar ${ }^{1}$, Arvyaty $^{2}$, Busnawir $^{3}$, Fahinu $^{3}$ \\ ${ }^{1}$ Alumnus Jurusan Pendidikan Matematika FKIP Universitas Halu Oleo \\ ${ }^{2}$ Dosen Pendidikan Matematika FKIP Universitas Halu Oleo; Co-author: arvyaty@gmail.com \\ ${ }^{3}$ Dosen Pendidikan Matematika FKIP dan PPS Universitas Halu Oleo
}

\begin{abstract}
Abstrak: Penelitian ini dilatarbelakangi oleh rendahnya kemampuan pemahaman konsep matematis siswa. Penelitian ini bertujuan untuk mengetahui pengaruh model pembelajaran generatif terhadap kemampuan pemahaman konsep matematis siswa kelas VIII SMP Negeri 12 Kendari.Populasi penelitian ini adalah seluruh siswa kelas VIII SMP Negeri 12 Kendari. Sampel diambil secara purposive sampling dan diperoleh kelas VIII5 sebagai kelas eksperimen. Data dikumpulkan dengan pemberian instrumen berupa lembar observasi dan tes kemampuan pemahaman konsep matematis yang berbentuk tes uraian. Analisis data menggunakan statistik deskriptif dan statistik inferensial. Hasil penelitian secara deskriptif dan secara inferensial menunjukkan bahwa: (1) Kemampuan pemahaman konsep matematis siswa sebelum menggunakan model pembelajaran generatif memiliki nilai rata - rata 61,77 dan varians 126,16. (2) Rata-rata kemampuan pemahaman konsep matematis siswa setelah pembelajaran generatif adalah 78,93 dan varians 138,78; dan (3) Terdapat pengaruh model pembelajaran generatif terhadap kemampuan pemahaman konsep matematis siswa kelas VIII SMP Negeri 12 Kendari.
\end{abstract}

Kata kunci: Model Pembelajaran Generatif, Matematika, Pemahaman Konsep Matematis.

\begin{abstract}
This research is motivated by the low ability to understand students' mathematical concepts. This study aims to determine the effect of generative learning models on the ability to understand mathematical concepts of eighth grade students of SMP Negeri 12 Kendari. The population of this study were all eighth grade students of SMP Negeri 12 Kendari. Samples were taken by purposive sampling and obtained class VIII5 as an experimental class. Data was collected by giving instruments in the form of observation sheets and tests on the ability to understand mathematical concepts in the form of a description test. Data analysis uses descriptive statistics and inferential statistics. Descriptive and inferential research results show that: (1) The ability to understand students' mathematical concepts before using generative learning models has an average value of 61.77 and variance 126.16. (2) The average ability to understand students' mathematical concepts after generative learning is 78.93 and variance 138.78; and (3) There is an effect of generative learning model on the ability to understand mathematical concepts of eighth grade students of SMP Negeri 12 Kendari.
\end{abstract}

Keywords: Generative Learning Model, Mathematics, Understanding The Mathematical Concepts

\section{PENDAHULUAN}

Pendidikan adalah usaha sadar dan terencana untuk mewujudkan suasana belajar dan proses pembelajaran agar peserta didik secara aktif mengembangkan potensi dirinya untuk memiliki kekuatan spiritual keagamaan, pengendalian diri, kepribadian, kecerdasan, akhlak mulia, serta keterampilan yang diperlukan dirinya, masyarakat, bangsa dan Negara (Rochaety, 2005: 6).

Pemahaman konsep matematika merupakan salah satu tujuan yang mendasar dalam proses pembelajaran dan salah satu tujuan dari materi yang 
disampaikan oleh guru. Pengetahuan dan pemahaman siswa terhadap konsep matematika menurut NCTM (National Council Of Teachers Of Mathematics) dapat dilihat dari kemampuan siswa dalam: (1) Mendefinisikan konsep secara verbal dan tulisan; (2) Mengidentifikasi dan membuat contoh dan bukan contoh; (3) Menggunakan model, diagram dan simbol-simbol untuk merepresentasikan suatu konsep; (4) Mengubah suatu bentuk representasi ke bentuk lainnya; (4) Mengenal berbagai makna dan interpretasi konsep; (5) Mengidentifikasi sifat-sifat suatu konsep dan mengenal syarat yang menentukan suatu konsep; dan (6) Membandingkan dan membedakan konsep-konsep. Namun, salah satu masalah yang sering muncul dalam pembelajaran matematika adalah rendahnya kemampuan siswa dalam menyelesaikan masalah matematika yang dikemas dalam bentuk soal yang lebih menekankan pada pemahaman konsep suatu pokok bahasan tertentu. Indikasinya dapat dilihat dari hasil belajar yang kurang memuaskan. Hal tersebut dikarenakan matematika yang bersifat abstrak dan membutuhkan pemahaman konsep-konsep dasar. Faktor lain yang berpengaruh adalah cara mengajar guru yang tidak tepat.

Berdasarkan hasil wawancara dengan salah seorang guru matematika SMP Negeri 12 Kendari pada tanggal 5 Februari 2018 diperoleh fakta bahwa kemampuan pemahaman konsep matematis siswa masih kurang baik. Kurangnya kemampuan siswa dalam pemahaman konsep matematis berdampak pada pencapaian hasil belajar yang masih rendah. Hal ini dapat dilihat dari nilai ratarata ulangan semester satu secara berturutturut yaitu 44,76; 44,7; 46,28; 43,15; 42,$45 ; 47,05$; dan 44,20. Menurut guru tersebut, kesalahan yang banyak dilakukan oleh siswa adalah masalah-masalah dalam hal menyelasaikan persoalan terkait konsep yang diberikan. Berdasarkan hasil identifikasi pada wawancara dengan guru matematika, diperoleh beberapa kelemahan siswa antara lain, memahami kalimat-kalimat dalam soal, membedakan informasi yang diketahui dan permintaan soal, menemukan keterkaitan dari informasi-informasi yang diketahui menggunakan pengetahuan atau ide yang diketahui, dan menggunakan cara atau strategi yang berbeda-beda dalam merencanakan penyelesaian suatu masalah, mengembangkan masalah berdasarkan kondisi yang diberikan, dan melakukan perhitungan. Kenyataan ini menunjukkan bahwa pemahaman konsep matematika siswa perlu diselesaikan.

Permasalahan lain, yang sering muncul adalah siswa masih menganggap matematika sebagai mata pelajaran yang sulit. Untuk mengatasi permasalahan tersebut, maka guru harus memikirkan cara-cara yang harus dilakukan agar dapat menyelesaikan masalah tersebut. Salah satunya adalah dengan mengubah model pembelajaran yang selama ini digunakan guru. Hal ini dikarenakan, pembelajaran bukanlah proses yang didominasi oleh guru sendiri, melainkan siswa juga ikut serta aktif di dalamnya. Oleh sebab itu, diperlukan suatu upaya untuk menyelesaikan masalah tersebut, yaitu menerapkan pembelajaran yang dirancang dan dilaksanakan dengan baik sehingga dapat membantu berkembangnya kemampuan pemahaman konsep siswa. Dari beberapa model pembelajaran yang mendukung peningkatan kemampuan pemahaman konsep siswa, peneliti tertarik untuk menerapkan model pembelajaran generatif dalam belajar mengajar di kelas.

Model pembelajaran generatif menekankan pengintegrasian aktif materi baru dengan pengetahuan yang ada dibenak siswa dan mengucapkan dengan kata-kata sendiri apa yang telah mereka dengar. Pembelajaran yang efektif dimana siswa terlibat langsung dalam situasi kognitif yaitu yang berkenaan dengan perilaku dalam aspek berpikir, aktifitas 
otak, keterampilan memecahkan masalah. Model pembelajaran generatif berbasis pada pandangan konstruktivisme yang intinya bahwa pebelajar mengkontruksi pengetahuan sainsnya sendiri dalam lingkungan belajar konstruktivis (Mardana, 2001: 51).

Kemampuan pemahaman matematik adalah salah satu tujuan penting dalam pembelajaran, memberikan pengertian bahwa materi-materi yang diajarkan kepada siswa bukan hanya sebagai hafalan, namun lebih dari itu dengan pemahaman siswa dapat lebih mengerti akan konsep materi pelajaran itu sendiri (Hodijah, 2014:351). Sementara Mulyasa (2005: 78) menyatakan bahwa pemahaman adalah kedalaman kognitif dan afektif yang dimiliki oleh individu.

Pemahaman konsep merupakan salah satu kecakapan atau kemahiran matematika yang diharapkan dapat tercapai dalam belajar matematika yaitu dengan menunjukkan pemahaman konsep matematika yang dipelajarinya, menjelaskan keterkaitan antar konsep dan mengaplikasikan konsep atau algoritma secara luwes, akurat, efisien, dan tepat dalam pemecahan masalah (Depdiknas, 2003: 2). Pemahaman menurut Taksonomi Bloom dalam Susilana (2006: 35) ada tiga macam pemahaman matematis, yaitu: pengubahan (translation), pemberian arti (interpretasi) dan pembuatan ekstrapolasi (ekstrapolation).

Indikator kemampuan pemahaman konsep yaitu: (1) Menyatakan ulang sebuah konsep; (2) Mengklasifikasikan objek-objek menurut sifat-sifat tertentu (sesuai dengan konsepnya); (3) Memberi contoh dan non contoh dari konsep; (4) Menyajikan konsep dalam berbagai bentuk representasi matematis;

Mengembangkan syarat perlu atau syarat cukup dari konsep; (6) Menggunakan prosedur atau operasi tertentu; (7) Mengaplikasikan konsep atau algoritma pemecahan masalah (Fadjar, 2009: 13).
Menurut Anderson dalam Kesumawati (2010: 22-23), pemahaman terdiri dari tujuh jenis, yaitu interpreting (menginterpretasikan), exemplifying (memberi contoh), classifying (mengklasifikasikan), summarizing (meringkas), inferring (menyimpulkan), comparing (membandingkan), dan explaning (menjelaskan).

Fahinu (2007: 40) mengungkapkan bahwa model pembelajaran generatif adalah proses aktif dalam mengkonstruksi pengetahuan baru berdasarkan pengetahuan yang telah dimiliki sebelumnya. Dalam pembelajaran generatif, siswa diharapkan dapat menghubungkan pengetahuan baru dengan pengetahuan yang sudah ada dengan melibatkan pengetahuan dan konsepsi awal yang akan menghasilkan pemaknaan dan pemahaman siswa dalam pembelajaran matematika.

Model pembelajaran generatif terdiri atas empat tahap pembelajaran yaitu: eksplorasi, pemfokusan, tantangan, dan penerapan konsep atau aplikasi. Dengan menghubungkan pengetahuan awal (prior knowledge) yang telah dimiliki sebelumnya dengan konsep yang dipelajari, akhirnya siswa dapat mengkonstruksi pengetahuan yang baru (Wena, 2010: 183).

Osborne dan Cosgrove dalam Sutarman dan Swasno (2003: 157), tahapan penerapan model pembelajaran generatif ini dapat dijabarkan dalam tahapan-tahapan dibawah ini:

1. Tahapan pendahuluan/ eksplorasi. Tahapan eksplorasi ini guru membimbing siswa untuk melakukan eksplorasi terhadap pengetahuan, ide, atau konsepsi awal yang diperoleh dari pengalaman sehari-hari atau diperoleh dari pembelajaran pada tingkatan kelas sebelumnya. Untuk melakukan eksplorasi diberikan stimulus berupa aktivitas/ tugas-tugas seperti penelusuran terhadap suatu 
permasalahan yang dapat menunjukan data atau fakta yang terkait dengan konsepsi yang akan dipelajari. Dengan kondisi yang demikian, pada akhirnya diharapkan muncul pertanyaan pada diri siswa, mengapa hal itu terjadi dan selanjutnya mengajak dan mendorong siswa untuk berdiskusi tentang fakta atau gejala yang baru diselidiki atau amati. Guru mengantarkan proses diskusi guna mengidentifikasi konsepsi siswa yang selanjutnya dapat dikembangkan menjadi rumusan, dugaan dan hipotesis.

2. Tahapan Pemfokusan. Pada tahap pemfokusan siswa melakukan pengujian hipotesis melalui kegiatan laboratorium atau dalam model pembelajaran yang lain. Guru sebagai fasilitator yang menyangkut kebutuhan sumber, memberi bimbingan dan arahan, dengan demikian para siswa dapat melakukan proses ilmiah. Tugas yang diberikan dalam pembelajaran sedemikian rupa hingga memberi peluang dan merangsang siswa untuk menguji hipotesisnya dengan caranya sendiri. Tugas-tugas pembelajaran yang disusun/dibuat guru hendaknya tidak seratus persen merupakan petunjuk atau langkah kerja, tetapi tugas-tugas haruslah memberikan kemungkinan siswa beraktivitas sesuai caranya sendiri atau cara yang diinginkan. Penyelesaian tugas dilakukan secara berkelompok yang terdiri atas 2 sampai dengan 4 siswa sehingga siswa dapat berlatih untuk meningkatkan sikap seperti ilmuwan. Misalnya pada aspek kerjasama dengan sesama teman sejawat, mebantu dalam kerja kelompok, menghargai pendapat teman, tukar pengalaman (sharing idea) dan keberanian bertanya.

3. Tahapan Tantangan. Tahapan tantangan disebut juga tahap pengenalan konsep. Setelah siswa memperoleh data, selanjutnya menyimpulkan dan menulis dalam lembar kerja. Siswa mempresentasikan temuanya melalui diskusi kelas. Melalui diskusi kelas akan terjadi proses tukar pengalaman diantara siswa. Dalam tahap ini siswa berlatih untuk mengeluarkan ide, kritik, berdebat, menghargai pendapat teman dan menghargai adanya perbedaan diantara pendapat teman. Pada akhir diskusi siswa memperoleh kesimpulan dan pemantapan konsep yang benar dengan proses kognitif yaitu terjadinya proses mental yang disebut asimilasi dan akomodasi. Proses asimilasi apabila konsepsi siswa sesuai dengan konsep benar menurut data eksperimen terjadi proses akomodasi apabila konsepsi siswa sesuai dengan data empiris. Pada tahap ini pula sebaiknya guru memberikan pemantapan konsep dan latihan soal agar siswa memahami secara mantap konsep tersebut. Pemberian soal dari yang mudah menuju paling sulit agar motivasi tidak menurun.

4. Tahapan Penerapan Konsep. Tahap keempat siswa diajak untuk memecahkan masalah dengan menggunakan konsep barunya dan konsep benar dalam situasi baru yang berkaitan dengan hal-hal praktis dalam kehidupan sehari-hari. Pada tahap ini pemberian soal-soal latihan diberikan lebih banyak agar lebih memahami konsep (isi pembelajaran) secara mendalam dan bermakna. Pada akhirnya konsep yang dipelajari siswa akan masuk ke memori jangka panjang sehingga tingkat retensi siswa semakin baik.

Keunggulan model pembelajaran generatif menurut Sugiarta, adalah:

1. Sangat baik untuk mengaktifkan anak dalam kegiatan pembelajaran termasuk pada anak-anak yang kurang mampu (tingkat pemahamannya lamban). 
2. Anak terangsang dan terbiasa mengerjakan tugas secara mandiri maupun kelompok,

3. Suasana belajar selama kegiatan pembelajaran nampak bebas, ceria, bergairah (penuh semangat), dan responsif (kondusif),

4. Hubungan anak dengan anak, anak dengan guru menjadi dekat (akrab)

\section{METODE PENELITIAN}

Penelitian ini termasuk penelitian eksperimen semu dengan menerapkan model pembelajaran generatif pada materi Peluang di kelas VIII SMP 12 Kendari. Penelitian ini dilaksanakan di kelas VIII SMP Negeri 12 Kendari, pada semester II dan sangat membantu pemecahan berbagai masalah yang dihadapi anak dalam proses pembelajaran,

5. Suasana "menggurui" oleh guru intensitasnya menurun karena guru lebih banyak berperan sebagai pendamping atau pembimbing dan fasilitator dalam kegiatan diskusi(Santi, 2011: 20).

\begin{tabular}{|c|c|c|c|}
\hline No. & Kelas & Jumlah Siswa & Nilai Rata-Rata UAS \\
\hline 1. & VIII $_{1}$ & 40 & 44,76 \\
\hline 2. & $\mathrm{VIII}_{2}$ & 39 & 44,70 \\
\hline 3. & $\mathrm{VIII}_{3}$ & 40 & 46,28 \\
\hline 4. & $\mathrm{VIII}_{4}$ & 40 & 43,15 \\
\hline 5. & $\mathrm{VIII}_{5}$ & 40 & 42,45 \\
\hline 6. & $\mathrm{VIII}_{6}$ & 38 & 47,05 \\
\hline 7 & $\mathrm{VIII}_{7}$ & 39 & 44,20 \\
\hline
\end{tabular}

Sampel dalam penelitian ini ditentukan menggunakan teknik purposive sampling dengan melihat nilai rata-rata matematika pada ulangan semester ganjil tahun ajaran 2017/2018. Berdasarkan teknik pengambilan sampel tersebut, diperoleh kelas $\mathrm{VIII}_{5}$ sebagai sampel penelitian.

Desain penelitian yang digunakan adalah one group pretest-posttest design dengan desainnya adalah sebagai berikut

$$
\begin{array}{lll}
\mathrm{O}_{1} & \mathrm{X} & \mathrm{O}_{2}
\end{array}
$$

(Sarwono, 2007: 86)

Keterangan:

$\mathrm{O}_{1}=$ Tes pemahaman konsep matematis siswa sebelum diajar dengan tahun ajaran 2017/2018. Populasi dalam penelitian ini adalah seluruh siswa kelas VIII SMP Negeri 12 Kendari. Populasi siswa kelas VIII SMP Negeri 12 Kendari beserta hasil ulangan semester 1 digambarkan pada tabel 1 . 
Aturan konversi nilai perolehan siswa adalah sebagai berikut:

$$
\text { Nilai }=\frac{\text { skor perolehan siswa }}{\text { skor maksimum }} \times 100
$$

Analisis data dalam penelitian ini menggunakan analisis deskriftif dan analisis inferensial. Analisis deskriptif diperlukan untuk mendeskripsikan atau menggambarkan data yang terkumpul

\section{HASIL PENELITIAN}

Hasil analisis data aktivitas guru dalam mengelola pembelajaran berdasarkan daftar aktifitas guru yang tertera pada lembar observasi yang ada sebagaimana adanya tanpa bermaksud membuat kesimpulan yang berlaku untuk populasi. Analisis inferensial dimaksudkan untuk menguji hipotesis penelitian, namun terlebih dahulu melalui tahapan yang lain, yaitu uji normalitas dan uji homogenitas sebagai prasyarat untuk pengujian hipotesis.

Tabel 2 Deskripsi Aktivitas Guru dalam Pelaksanaan Pembelajaran dengan Model Pembelajaran Generatif

\begin{tabular}{ccc}
\hline Pertemuan & Skor Total Keberhasilan Guru & Persentase (\%) \\
\hline Pertama & 13 & 72,22 \\
Kedua & 15 & 83,33 \\
Ketiga & 16 & 88,89 \\
Keempat & 17 & 94,44 \\
\hline
\end{tabular}

Hasil observasi pengelolaan pembelajaran oleh guru selama pembelajaran sebagaimana disajikan pada Tabel 2, keberhasilan pengelolaan pembelajaran pada pertemuan pertama sudah baik dengan tingkat keberhasilan sebesar $72,22 \%$ yang dimana pengelolaan pembelajaran pada pertemuan pertama sudah masuk dalam kriteria efektif. Pelaksanaan pembelajaran pada pertemuan kedua mengalami peningkatan yang baik dengan tingkat keberhasilan mencapai 83,33\% dengan kategori sangat baik yang pada setiap pembelajaran menggunakan model Generatif, terdiri dari empat pertemuan, disajikan dalam tabel 2 .

Tabel 3 Hasil Observasi Aktivitas Siswa

\begin{tabular}{lcc}
\hline \multicolumn{1}{c}{ Pertemuan } & Skor Perolehan (Keterlaksanaan) & Persentase (\%) \\
\hline Pertama & 9 & 64,28 \\
Kedua & 11 & 78,57 \\
Ketiga & 12 & 85,71 \\
Keempat & 13 & 92,85 \\
\hline
\end{tabular}

Berdasarkan tabel tersebut, pertemuan ketiga mengalami peningkatan yang baik dengan tingkat keberhasilan mencapai $88,89 \%$. Sedangkan pada pertemuan keempat tingkat keberhasilan mencapai 94,44\%.

Data aktivitas siswa yang tertera pada lembar observasi yang ada pada setiap pembelajaran menggunakan model Generatif, terdiri dari empat pertemuan, disajikan dalam tabel 3. persentase keaktifan siswa pada semua seluruh aspek yang diamati mengalami

pertemuan dengan ketercapaian dari 
peningkatan yang lebih baik lagi. Hal ini menunjukan bahwa siswa bisa melakukan pembelajaran lebih baik lagi dengan menggunakan model pembelajaran generatif.
Distribusi data hasil pretest dan posttest kemampuan pemahaman konsep matematis siswa dapat dilihat pada Tabel 4.

Tabel 4. Distribusi Data Pretest dan Posttest Kemampuan Pemahaman Konsep Matemastis Siswa

\begin{tabular}{ccccccc}
\hline \multirow{2}{*}{ No. Nilai } & \multirow{2}{*}{ Kriteria } & F & Persentase $(\%)$ & F & Persentase (\%) \\
\cline { 4 - 7 } & & & 0 & 0 & 15 & 37,5 \\
1 & $85,00-100$ & Sangat baik & 0 & 27,5 & 18 & 45 \\
2 & $70,00-84,99$ & Baik & 11 & 50 & 4 & 10 \\
3 & $55,00-69,99$ & Cukup & 20 & 12,5 & 3 & 7,5 \\
4 & $40,00-54,99$ & Rendah & 5 & 10 & 0 & 0 \\
5 & $0,00-39,99$ & Sangat Rendah & 4 & 100 & 40 & 100 \\
\hline \multicolumn{2}{c}{ Jumlah } & 40 & 100 &
\end{tabular}

Berdasarkan tabel 4 tampak bahwa, sebelum dilaksanakan pembelajaran dengan model pembelajaran generatif kemampuan pemahaman konsep matematis siswa berada pada kategori baik, cukup, rendah, dan sangat rendah. Tampak bahwa pada pretest tidak ada satupun siswa yang berada pada kategori sangat baik. Berdasarkan hasil analisis tersebut, dapat disimpulkan bahwa kemampuan pemahaman konsep matematis siswa tergolong cukup.

Setelah dilaksanakan pembelajaran dengan model pembelajaran generatif, kemampuan pemahaman konsep matematis siswa berada pada kategori sangat baik, baik, cukup, dan rendah. berbeda dengan hasil pretest dimana tidak seorangpun siswa yang berada pada kategori sangat baik, pada posttest terdapat 15 orang siswa yang berada pada kategori sangat baik. Berdasarkan hasil analisis tersebut, maka dapat disimpulkan bahwa kemampuan pemahaman konsep matematis siswa terkait dengan materi peluang mengalami peningkatan setelah diajar dengan model pembelajaran generatif.

Data hasil n-gain penelitian, menghasilkan data klasifikasi normalized gain yang disajikan pada tabel 5 berikut:

Tabel 6. Distribusi Frekuensi Berdasarkan Kriteria Data $\boldsymbol{n}$-gain Kemampuan Pemahaman Konsep Matematis Siswa

\begin{tabular}{cccc}
\hline Normalized Gain & Kriteria & $\boldsymbol{F}$ & $\boldsymbol{f}(\boldsymbol{\%})$ \\
\hline$N$-Gain $\geq 0,70$ & Tinggi & 1 & 2,5 \\
$0,30 \leq N$-Gain $<0,70$ & Sedang & 35 & 87,5 \\
$N$-Gain $<0,30$ & Rendah & 4 & 10 \\
\hline
\end{tabular}

Berdasarkan tabel tersebut, terdapat 1 siswa $(2,5 \%)$ memperoleh kriteria $n-$ gain kategori tinggi, 35 siswa $(87,5 \%)$ memperoleh kriteria $n$ - gain kategori sedang, dan 4 siswa memperoleh kriteria $n$ - gain kategori rendah. Rerata nilai normalized gain yang diiperoleh adalah
0,47 sehingga termasuk dalam kategori sedang, dengan nilai normalized gain terbesar adalah 0,96 dan nilai normalized gain terkecil 0,12

Analisis inferensial dilakukan untuk menguji hipotesis penelitian. Sebelum dilakukan pengujian hipotesis terlebih 
dahulu dilakukan uji normalitas sebagai prasyarat untuk pengujian hipotesis. Hasil uji normalitas data menunjukkan data pretest dan posttest berdistribusi normal.

Pengujian pengaruh model pembelajaran generatif terhadap kemampuan pemahaman konsep matematis siswa digunakan uji t sampel berpasangan (paired sample t-test). Rumusan hipotesis yang diuji adalah:

$\mathrm{H}_{0}: \mu_{d} \leq 0$ lawan $\mathrm{H}_{1}: \mu_{d}>0$

Keterangan:

$$
\begin{aligned}
\mu_{d}= & \text { rata-rata selisih kemampuan } \\
& \text { pemahaman konsep matematis } \\
& \text { siswa sebelum dan setelah } \\
& \text { diajar dengan model } \\
& \text { pembelajaran generatif. }
\end{aligned}
$$

Kriteria pengujian yang digunakan adalah nilai $t_{\text {hitung }}$ lebih besar dari $t_{\text {tabel }}$ maka $\mathrm{H}_{0}$ ditolak atau dengan melihat nilai sig. $\left(\frac{2-\text { tailed }}{2}\right)$ yakni, jika nilai sig. $\left(\frac{2-\text { tailed }}{2}\right)$ lebih besar dari $(\alpha=0,05)$; maka $\mathrm{H}_{0}$ diterima.

Tabel 8 Hasil uji $t$ (uji perbedaan rata - rata) data berpasangan pretest-posttest

\begin{tabular}{cccc}
\hline & $\boldsymbol{t}$ hitung & Sig $(\mathbf{2}-$ tailed $)$ & Keputusan \\
\hline Pretest - Posttest & $-17,666$ & 0,000 & Tolak $\mathrm{H}_{0}$ \\
\hline
\end{tabular}

Berdasarkan tabel tersebut, jika dilihat dari uji $\mathrm{t}$ dengan $\mathrm{df}=39$ dan signifikansi $\alpha=5 \%$ diperoleh $t_{\text {tabel }}=2,022$. Dengan menggunakan nilai $\mathrm{t}$ hitung untuk pengambilan keputusan dimana Terima $\mathrm{H}_{0}$ jika $-t_{h i t} \geq-t_{\alpha ;(n-1)}$, karena $\quad-t_{\text {hit }}=-17,666<-2,022=$ $-t_{\text {tabel }}$ dan nilai Sig $t_{\text {hit }}(2-$ tailed $)=$ 0,000 , dalam hal ini Sig $t_{\text {hit }}(2-$ tailed $)<$

\section{PEMBAHASAN}

Penelitian ini dilaksanakan selama lima kali pertemuan, dimana pertemuan pertama hingga keempat dilaksanakan pembelajaran dengan materi ajar yang diberikan adalah "Peluang". Setelah empat kali pertemuan pembelajaran, pada pertemuan kelima dilaksanakan posttest.

Guru pengajar pada pelaksanaan pembelajaran di kelas adalah peneliti. Pengamat aktivitas guru pengajar dilakukan oleh guru mata pelajaran, dan pengamat aktivitas siswa dilakukan oleh peneliti bersama dengan guru mata pelajaran matematika dari SMPN 12 Kendari. Alokasi waktu pembelajaran di kelas adalah $10 \times 40$ menit pelajaran, sedangkan pada saat pelaksanaan posttest diberikan alokasi waktu masing - masing 90 menit.
0,05, sehingga diputuskan Tolak $\mathrm{H}_{0}$. Artinya terdapat pengaruh yang signifikan rata-rata selisih kemampuan pemahaman konsep matematis siswa sebelum dan setelah diajar dengan model pembelajaran generatif siswa kelas VIII 5 SMP Negeri 12 Kendari..

Model pembelajaran generatif terdiri dari empat tahap, yaitu tahap pendahuluan/ eksplorasi, tahap pemfokusan, tahap tantangan dan tahap aplikasi, namunn pada pelaksanaanya terdiri dari lima tahap, empat tahap tersebut ditambah tahap penutup.

Sebelum dimulai tahap pendahuluan/eksplorasi, guru menunjuk seorang pada masing-masing kelompok untuk bertugas sebagai koordinator, dan berfungsi sebagai pemantau adanya siswa yang kurang aktif dan tidak mau bekerja sama, setelah itu siswa diberikan lembar kerja (LKS) yang berisi empat tahapan generatif. Tugas pertama siswa pada tahap pendahuluan/ekpolasi adalah membaca, memahami dan memecahkan suatu masalah. Pada dasarnya tahap pendahuluan/ekplorasi ini merupakan 
tahapan dasar yang melatih siswa untuk mengeksplorasi pengetahuan, ide atau konsepsi awal yang diperoleh dari pengalaman sehari-hari atau diperoleh dari pembelajaran pada tingkat kelas sebelumnya. Dibutuhkan ide-ide dari setiap anggota kelompok dalam kelompok untuk memecahkan masalah yang ada.

Informasi dari siswa bahwa dalam pembelajaran sebelum penelitian, selama ini siswa jarang belajar dengan metode diskusi kelompok seperti yang dihadapi dalam pembelajaran generatif. Selain itu, mayoritas siswa juga tidak menguasai materi prasyarat terkait materi peluang. Langkah guru untuk mengatasi masalah ini adalah mencoba untuk membangun pemahaman siswa dengan menjelaskan cara kerja dan penyelesaian masalah ke masing-masing kelompok.

Selanjutnya, guru mendorong dan merangsang siswa untuk mengemukakan ide/ pendapat tentang apa yang telah diperoleh setelah mengamati masalah yang di sajikan di LKS. Hal ini perlu dilakukan untuk melatih sikap percaya diri siswa dalam mengungkapkan ide - ide mereka dan sebagai ajang berbagi informasi ke sesama siswa dikelompok lain. Guru mempersilakan siswa untuk mengklasifikasi pendapat siswa lain tentang apa yang telahh diperoleh setelah mengamati masalah terkait yang disajikan di LKS.

Pada tahap pemfokusan, guru membimbing dan mengarahkan siswa untuk menetapkan konteks permasalahan berkaitan dengan ide siswa yang kemudian dilakukan pengujian. Hal ini bertujuan agar siswa siswa mampu menetapkan konteks permasalahan, memahami, mencermati permasalahan sehingga siswa menjadi familiar terhadap bahan yang digunakan untuk mengeksplorasi konsep. Melalui tahap kedua in, siswa dipacu untuk mengumpulkan informasi yang diharapkan mengembangkan berpikir rasa ingin tahu, tanggung jawab, dan menghargai pendapat orang lain. Namun yang menjadi kekurangannya adalah beberapa siswa terlihat kurang percaya diri dan tidak bekerja sama dalam proses penyelesaian masalah.

Pada tahap ketiga, yakni tantangan disebut juga pengenalan konsep. Setelah siswa memperoleh data selenjutnya siswa menyimpulkan dan menulis dalam lembar kerja. Para siswa mempresentasikan temuannya melalui diskusi kelas. Melalui diskusi kelas akan terjadi proses tukar pengalaman diantara siswa. Dalam tahap ini siswa berlatih untuk berani mengeluarkan ide, kritik, berdebat, menghargai pendapat teman, dan menghargai adanya perbedaan diantara pendapat teman. Pada saat diskusi guru berperan sebagai moderator agar jalannya diskusi dapat terarah. Pada akhir diskusi siswa memperoleh kesimpulan dan pemantapan konsep yang benar.

Pada tahap keempat, yakni aplikasi/penerapan. Pada tahap ini siswa memecahkan masalah dengan menggunakan konsep dalam situasi yang baru, siswa menyelesaikan soal-soal yang ada di LKS menggunakan konsep yang didapatkan. siswa terlihat kesulitan dalam proses penyelesaian masalah, sehingga guru harus membantu dan membimbing mereka dalam memecahkan masalah tersebut. Karena waktu yang tidak memungkinkan untuk mengunjungi masing-masing kelompok, peneliti memilih untuk menjelaskan sekilas mengenai cara menyelesaikan masalah tersebut. sebelum pembelajaran berakhir guru dan siswa bersama - sama menarik kesimpulan akhir mengenai materi yang dipelajari hari itu.

Pembelajaran pada pertemuan tersebut menjadi "cermin" bagi peneliti dan siswa pada pertemuan selanjutnya. Pada pertemuan kedua guru dan siswa dapat dikatakan berhasil melaksanakan tahap pembelajaran, meskipun ada dua tahap kegiatan inti, siswa sempat 
mengalami kesulitan dalam memecahkan masalah, namun dengan perlahan peneliti mengarahkan siswa dalam diskusi, sehingga diskusi berjalan lebih lancar. Lancarnya kegiatan pembelajaran hari itu tidak terlepas dari peran siswa yang sangat antusias mengikuti pembelajaran. Juga, hadirnya siswa dengan kemampuan lebih baik dari anggota lain dalam setiap kelompok cukup memberikan hasil positif terhadap lancarnya proses pembelajaran.

Masalah yang sering dialami siswa pada pertemuan-pertemuan selanjutnya adalah dalam menghadapi tahap pemfokusan, sebab mereka relatif tidak mampu untuk mengklarifikasi ide ke dalam konsep terhadap masalah yang ada di LKS, yaitu masalah aplikatif materi pada kehidupan sehari-hari. Untuk mengatasi masalah ini, guru membimbing siswa melalui tanya - jawab pada kelompok masing-masing, sedangkan pada pertemuan keempat, cara pada pertemuan ketiga tersebut dirasa tidak efektif lagi. Guru tidak lagi mengunjungi satu persatu kelompok untuk membimbing siswa, melainkan menjelaskannya didepan kelas. Disaat bersamaan, guru dan siswa melakukan tanya-jawab terhadap langkahlangkah pemecahan masalah kehidupan nyata tersebut.

Berdasarkan hasil observasi aktivitas guru dan siswa, dapat dikatakan bahwa pencapaian keterlaksanaan pembelajaran tergolong berhasil (> 80\%). Setelah proses pembelajaran selesai, pada pertemuan terakhir diadakan posttest. Kemudian, data hasil posttest tersebut diolah menggunakan SPSS untuk menguji apakah dengan

\section{KESIMPULAN DAN SARAN}

Berdasarkan hasil penelitian dan pembahasan, maka dapat ditarik beberapa kesimpulan berikut:

1. Kemampuan pemahaman konsep matematis siswa setelah diajar menggunakan model pembelajaran generatif memiliki nilai rata - rata 78,93 nilai rata-rata ini termasuk dalam model pembelajaran generatif memberikan pengaruh pada kemampuan pemahaman konsep siswa kelas VIII SMP Negeri 12 Kendari.

Hasil analisis deskriptif data pretest dan postest menunjukkan rataan nilai siswa dalam hal ini menggambarkan kemampuan pemahaman konsep matematisnya, setelah diajar menggunakan model pembelajaran generatif lebih tinggi dibandingkan sebelum diajar menggunakan model pembelajaran generatif yakni untuk pretest 61,77 dan posttest 78,93

Secara deskriptif, dapat diketahui bahwa terdapat peningkatan kemampuan pemahaman konsep matematis siswa setelah diajar dengan menggunakan model pembelajaran generatif. Namun, agar lebih jelas dalam melihat pengaruh model pembelajaran generatif terhadap kemampuan pemahaman konsep matematis siswa, maka dilakukan uji hipotesis dengan menggunakan uji-t sampel berpasangan.

Model pembelajaran generatif dapat meningkatkan kemampuan pemahaman konsep matematis. Hal ini berdasar pada hasil uji statistik, bahwa terdapat pengaruh yang signifikan model pembelajaran generatif terhadap kemampuan pemahaman konsep matematis siswa kelas VIII SMP Negeri 12 Kendari. Angka ini menunjukkan bahwa model pembelajaran generatif memberikan pengaruh pada kemampuan pemahaman konsep matematis

kategori baik. Varians dan std. deviasi masing-masing sebesar 138,78 dan 11,78. Hal ini menandakan bahwa data pada kelas $\mathrm{VIII}_{5}$ heterogen. Dengan kata lain, kemampuan pemahaman konsep matematis siswa kelas $\mathrm{VIII}_{5}$ beragam. Berdasarkan analisis data setelah diajar menggunakan model 
pembelajaran generatif, terdapat 15 siswa dengan kategori Sangat baik, 18 siswa baik, 4 siswa cukup, 3 siswa rendah dan tidak ditemukan siswa dalam kategori sangat rendah.

2. Berdasarkan hasil analisis deskripitif dan inferensial, menunjukkan bahwa Terdapat pengaruh Model pembelajaran generatif terhadap kemampuan pemahaman konsep matematis siswa kelas VIII 5 SMP Negeri 12 Kendari.

Berdasarkan hasil yang diperoleh dari penelitian ini, maka peneliti mengemukakan beberapa saran, yaitu:

1. Kepada guru yang mengajar mata pelajaran matematika dapat menggunakan model pembelajaran generatif sebagai salah satu alternatif dalam pembelajaran matematika untuk

\section{DAFTAR PUSTAKA}

Depdiknas. 2003. Pedoman Khusus Pengembangan Sistem Penilaian Berbasis Kompetensi SMP. Jakarta: Depdiknas.

Fadjar, Shadiq. 2009. Diklat Instruktur Pengembang Matematika SMA Jenjang Lanjut. Kemahiran Matematika. Yogyakarta : Departemen Pendidikan Nasional

Fahinu. 2007. Meningkatkan Kemampuan Berpikir Kritis dan kemandirian Belajar Matematika pada Mahasiswa melalui pembelajaran generatif. Desertasi Program Doktor Kependidikan dalam Pendidikan Matematika PPsUPI (Tidak dipublikasikan)

Hodijah, Yoyo. 2014. Pembelajaran Berbasis Masalah Untuk Meningkatkan Kemampuan Pemahaman Matematis. Program Pasca Sarjana STKIP Siliwangi Bandung. Prosiding Seminar Nasional Pendidikan Matematika, 1: 351. mengoptimalkan kemampuan pemahaman konsep matematis siswa

2. Dengan adanya beberapa keterbatasan dalam penelitian ini, sebaiknya dilakukan penelitian yang lebih lanjut untuk meneliti tentang pembelajaran dengan model pembelajaran generatif pada pokok bahasan yang cocok atau pada jenjang sekolah yang berbeda.

3. Sangat penting bagi guru mampu mengelola kelas dengan baik selama pelaksanaan pembelajaran dengan model pembelajaran generatif karena pada awal pembelajaran siswa mungkin akan kesulitan atau bahkan kurang kooperatif dalam pelaksanaan pembelajaran.
Kesumawati, Nila. 2010. Peningkatan Kemampuan Pemahaman, Pemecahan Masalah, dan Disposisi Matematis Siswa SMP melalui Pendekatan Pendidikan Matematika Realistik. Disertasi PPS UPI Bandung. Tidak Diterbitkan.

Mulyasa, E. 2003. Kurikulum Berbasis Kompetensi. Bandung: Remaja Rosda Karya

National Council of Teachers of Mathematics. Principles and Standars for School Mathematics. Reston, VA: NCTM.

Rochaety, dkk. 2005. Sistem Informasi Manajemen Pendidikan. Jakarta: PT Bumi Aksara

Santi, Putu. 2011. Penerapan Kelompok Belajar Kompetitif Dengan Model Pembelajaran Generatif Sebagai Upaya Untuk Meningkatkan Hasil Belajar Mata Pelajaran IPA di Kelas IV SD No. 4 Penarukan, Kecamatan Buleleng, Kabupaten Buleleng Tahun Pelajaran 2010/2011. Skripsi (tidak diterbitkan). Jurusan 
Pendidikan Guru Sekolah Dasar, FIP Undiksha

Sarwono, Jonathan. 2006. Metode Penelitian Kuantitatif \& Kualitatif. Yogyakarta: Graha Ilmu.

Susilana, R .2006. Kurikulum dan Pembelajaran. Bandung: TIM MKDP FKIP UPI

Sutarman dan Swasono, P. 2003. "Implementasi Pembelajaran Generatif Berbasis Konstruktivisme sebagai Upaya Meningkatkan Kemampuan Siswa Kelas III pada Bidang Fisika di SLTP 17 Malang". Malang: Lemlit-UM, 11 (2): 157.

Wena, M. 2010. Strategi Pembelajaran Inovatif Kontemporer. Jakarta: Bumi Aksara 